\title{
ANALISIS PENGENDALIAN INTERNAL PERSEDIAAN DAN PENERAPAN METODE JUST IN TIME TERHADAP \\ EFISIENSI BIAYA PERSEDIAAN BAHAN BAKU STUDI KASUS PT. SIIX ELECTRONICS INDONESIA
}

\author{
ANALYSIS INTERNAL CONTROL OF INVENTORY AND \\ IMPLEMENTATION JUST IN TIME METHOD ON EFFICIENCY \\ INVENTORY COST OF RAW MATERIAL \\ STUDY CASE IN PT. SIIX ELECTRONICS INDONESIA
}

\author{
Aznedra $^{1}$, Endah Safitri ${ }^{2}$ \\ ${ }^{1}$ (Akuntansi, Ekonomi, Universitas Riau Kepulauan, Indonesia) \\ ${ }^{2}$ (Akuntansi, Ekonomi, Universitas Riau Kepulauan, Indonesia) \\ 'nedrasukses@gmail.com
}

\begin{abstract}
Abstrak
Persediaan merupakan salah satu aktiva perusahaan, oleh karena itu harus memiliki pengendalian internal yang baik untuk menjaga persediaan tersebut dari hal-hal buruk yang mungkin terjadi dan berpengaruh pada efisiensi biaya persediaan bahan baku. Tujuan dari penelitian ini adalah untuk menganalisis sistem pengendalian internal persediaan dan penerapan metode just in time terhadap efisiensi biaya persediaan bahan baku PT. SIIX Electronics Indonesia. Jenis penelitian adalah deskriptif dengan pendekatan kualitatif, pengumpulan data dilakukan dengan metode observasi, wawancara dan dokumentasi. Hasil penelitian adalah pengendalian internal persediaan tidak berjalan dengan baik sehingga tidak ada efisiensi pada biaya persediaan bahan baku, begitupun dengan penerapan metode just in time tidak efisien terhadap biaya persediaan bahan baku.
\end{abstract}

Kata kunci: pengendalian internal, just in time, efisiensi biaya persediaan bahan baku

\section{Abstract}

Inventory is one of important asset company because of that company should have a good internal control of inventory to keep them from many things bad that might happen and affected to efficiency inventory cost of raw material. The purpose of this research is to analyze system of internal control and implementation just in time method to efficiency total inventory cost of raw material in PT. SIIX Electronics Indonesia. Type of research is descriptive with qualitative approach. Data collecting is done by observing, interview and documenting method. The result is internal control of inventory doesn't work properly, then no efficiency to inventory cost of raw materials, same condition for implementation just in time method no efficien to inventory cost of raw materials.

Keywords: internal control, just in time, efficiency inventory cost of raw materials

\section{PENDAHULUAN}

\section{Latar Belakang Masalah}

Adanya pengendalian internal yang baik dan teratur dalam mengelola persediaan bahan baku, akan membantu lancarnya produksi perusahaan secara umum, dan meningkatkan efektivitas perusahaan, serta membantu dalam mengambil kebijakan keputusan maupun pertanggungjawaban dalam memimpin perusahaan. Pengendalian internal atas bahan baku diharapkan dapat menciptakan aktivitas pengendalian terhadap perusahaan yang efektif dalam 
menentukan jumlah persediaan optimal yang dimiliki perusahaan, mencegah berbagai tindakan pelanggaran dan penyelewengan yang dapat merugikan perusahaan, pelanggaran terhadap kebijakan yang diterapkan atas persediaan, serta memberikan pengamanan fisik terhadap persediaan dari pencurian dan kerusakan.

PT. Siix Electronics Indonesia merupakan perusahaan manufacturing yang bergerak dalam perakitan atau assembly Image scanner dengan merk Fujitsu yang berpusat di Jepang. Image scanner merk Fujitsu hanya diproduksi di Indonesia yaitu di PT. Siix Electronics Indonesia yang terletak di Muka Kuning Pulau Batam.

Tingginya produksi yang dilakukan oleh PT. Siix Electronic Indonesia setiap harinya pasti mempengaruhi biaya persediaan pada akhir periode. Biaya persediaan akhir periode yang sudah ditetapkan oleh manajemen perusahaan sebesar USD 1.300.000 untuk semua persediaan raw materials. Oleh karena proses produksi yang berkelanjutan setiap harinya untuk memenuhi permintaan customer (PFU) yang sudah dijadwalkan untuk satu bulan penuh dalam dalam schedule production dan forecast untuk ramalan total produksi tiga bulan kedepan atau lebih, metode just in time delivery digunakan untuk meminimalkan biaya persediaan pada setiap akhir periode agar tidak melebihi target dari manajemen. Just in time delivery adalah pengiriman bahan baku saat dibutuhkan oleh produksi, pada prakteknya PT. SIIX Electronics Indonesia akan menjadwalkan pengiriman bahan baku satu hari atau kurang lebih 24 jam sebelum waktu produksi.

Berdasarkan uraian yang telah di jelaskan sebelumnya maka penulis akhirnya memilih judul "Analisis Pengendalian Internal Persediaan dan Penerapan Metode Just in time Terhadap Efisiensi Biaya Persediaan Bahan Baku PT. SIIX Electronics Indonesia".

\section{Tujuan Penelitian}

1. Untuk mengetahui penerapan pengendalian internal persediaan sudah berjalan secara efektif terhadap efisiensi persediaan bahan baku PT SIIX Electronics Indonesia.

2. Untuk mengetahui penerapan metode JIT sudah berjalan secara efektif terhadap efisiensi biaya persediaan bahan baku PT SIIX Electronics Indonesia.

\section{TINJAUAN PUSTAKA}

\section{Definisi Pengendalian Internal}

Menurut Mulyadi (2010:163) sistem pengendalian internal meliputi struktur organisasi, metode, dan ukuranukuran yang dikoordinasikan untuk menjaga kekayaan organisasi. Mengecek ketelitian dan keandalan data akuntansi, mendorong efisiensi dan mendorong dipatuhinya kebijakan manajemen.

\section{Unsur-Unsur Pengendalian Internal}

Menurut Mulyadi (2010:427-428) menyatakan bahwa ada empat unsur utama sistem pengendalian internal kas. Unsur-unsur tersebut adalah:

1. Struktur organisasi yang memisahkan tanggung jawab fungsional secara tegas.

2. Sistem wewenang dan prosedur pencatatan yang memberikan perlindungan yang cukup terhadap kekayaan, utang, pendapatan dan biaya.

3. Praktik yang sehat dalam melaksanakan tugas dan fungsi setiap unit dan organisasi.

4. Karyawan yang mutunya sesuai dengan tanggung jawabnya. 


\section{Pengertian Just in time}

Menurut Dra. Tita Deitiana, MM (2011:223), Just in time merupakan falsafah pemecahan masalah yang berkelanjutan dan memang harus dihadapi yang dapat menyebabkan sesuatu terbuang percuma.

Menurut Ricky Martono (2015:380) Just in time pertama kali dikembangkan dan disempurnakan di pabrik Toyota Manufacturing oleh Taiichi Ohno di Jepang, oleh karena itu Taiichi Ohno sering disebut sebagai bapak just in time (JIT). Kemudian just in time (JIT) diadopsi oleh banyak perusahaan manufaktur di Jepang dan Amerika Serikat seperti: Hewlet Packard (HP), IBM, dan Harley Davidson.

\section{Aspek Penting Just in time (JIT)}

Menurut Patrick Brisley (2000) dalam Carien Valerie Sakkung dan Candra Sinuriya 2011. Ada empat aspek penting dalam JIT, yaitu:

1. Penghapusan semua kegiatan yang tidak menambah nilai produk atau jasa

2. Diperlukan suatu komitmen untuk tingkat kualitas yang lebih tinggi.

3. Diperlukan suatu komitmen untuk perbaikan terus menerus dalam efisiensi kegiatan.

4. Penekanan pada penyederhanaan dan meningkatkan pengindentifikasian terhadap aktivitas yang tidak menambah nilai.

\section{Prinsip Dasar Just in time (JIT)}

Untuk mengaplikasikan metode just in time (JIT) ada tujuh prinsip yang harus dijadikan dasar pertimbangan di dalam menentukan strategi sistem produksi (Tjahjadi 2001:227 dalam Christyandhika dan Farida 2014), yaitu:

1. Berproduksi sesuai dengan pesanan jadwal produksi induk

Sistem manufaktur baru akan dioperasikan untuk menghasilkan produk menunggu setelah diperoleh kepastian adanya order dalam jumlah tertentu masuk. Tujuan utamanya untuk memproduksi finish good tepat waktu dan sebatas pada jumlah yang ingin dikonsumsi saja (just in time), untuk itu proses produksi akan menghasilkan sebanyak yang diperlukan dan secepatnya dikirim ke pelanggan yang memerlukan untuk menghindari terjadinya stok serta untuk menekan biaya penyimpanan (holding cost).

2. Produksi dilakukan dalam jumlah lot (Lot Size)

Jumlah yang kecil untuk menghindari perencanaan dan lead time yang kompleks seperti halnya dalam produksi jumlah besar. Fleksibilitas aktivitas produksi akan bisa dilakukan, karena hal tersebut memudahkan untuk melakukan penyesuaian-penyesuaian dalam rencana produksi terutama menghadapi perubahan permintaan pasar.

3. Mengurangi pemborosan (Eliminate Waste)

Pemborosan (waste) harus dieliminasi dalam setiap area operasi yang ada. Semua pemakaian sumber-sumber input (material, energi, jam kerja mesin atau orang, dan lain-lain) tidak boleh melebihi batas minimal yang diperlukan untuk mencapai target produksi.

4. Perbaikan aliran produk secara terus menerus

(Continous Product Flow Improvement) Tujuan pokoknya adalah menghilangkan proses-proses yang menimbulkan bottleneck dan semua kondisi yang tidak produktif (idle, delay, material handling, dan lain-lain) yang bisa menghambat kelancaran aliran produksi.

5. Penyempurnaan kualitas produk (Product Quality Perfection)

Kualitas produk merupakan tujuan dari aplikasi just in time (JIT) dalam sistem produksi. Disini selalu diupayakan untuk mencapai kondisi "Zero Defect" dengan 
cara melakukan pengendalian secara total dalam setiap langkah proses yang ada. Segala bentuk penyimpangan haruslah bisa diidentifikasikan dan dikoreksi sedini mungkin.

6. Respek terhadap semua orang atau karyawan (Respect to People)

Dengan metode just in time (JIT) dalam sistem produksi setiap pekerja akan diberi kesempatan dan otoritas penuh untuk mengatur dan mengambil keputusan apakah suatu aliran operasi bisa diteruskan atau harus dihentikan karena dijumpai adanya masalah serius dalam satu stasiun kerja tertentu.

7. Mengurangi segala bentuk ketidak pastian (Seek to Eliminate Contigencies)

Inventory yang ide dasarnya diharapkan bisa mengantisipasi permintaan yang berfluktuasi dan segala kondisi yang tidak terduga, justru akan berubah menjadi waste bilamana tidak segera digunakan. Begitu pula rekruitmen tenaga kerja dalam jumlah besar secara tidak terkendali seperti halnya yang umum dijumpai dalam aktivitas proyek akan menyebabkan terjadinya pemborosan bilamana tidak dimanfaatkan pada waktunya. Oleh karena itu dalam perencanaan dan penjadwalan produksi harus bisa dibuat dan dikendalikan secara teliti. Segala bentuk yang memberi kesan tidak pastian harus bisa dieliminir dan harus sudah dimasukkan dalam pertimbangan dan formulasi model peramalannya.

\section{Pengertian Efisiensi Biaya}

\section{Efisiensi}

Menurut (Adisasmita, 2011) efisiensi merupakan komponenkomponen input yang digunakan seperti waktu, tenaga dan biaya dapat dihitung penggunaannya dan tidak berdampak pada pemborosan atau pengeluaran yang tidak berarti.
Dari pemaparan tersebut di atas dapat simpulkan bahwa Efisiensi (E) adalah suatu konsepsi tentang perbandingan terbaik antara hasil yang diperolah output $(\mathrm{O})$ dengan usaha yang perlu dilakukan atau input (I). Ketiganya dapat dirumuskan sebagai $\mathrm{E}=\mathrm{O}>\mathrm{I}$.

\section{Biaya}

Menurut Mulyadi (2014:8), biaya adalah pengorbanan sumber ekonomi, yang diukur dengan satuan uang, yang telah terjadi untuk mencapai tujuan terntentu. Dari definisi tersebut di atas, ada empat unsur pokok dalam biaya, yaitu

1. Biaya merupakan pengorbanan sumber ekonomi.

2. Diukur dalam satuan uang.

3. Yang telah terjadi atau kemungkinan dapat terjadi.

4. Pengorbanan tersebut untuk memperoleh manfaat saat ini dan atau mendatang.

Dengan demikian, biaya adalah pengorbanan sumber ekonomis yang diukur dengan satuan uang, untuk memperoleh barang atau jasa yang diharapkan memberikan manfaat saat ini maupun yang akan datang. Pengorbanan sumber ekonomis dapat berupa biaya historis dan biaya masa yang akan datang.

\section{Efisiensi Biaya}

Berdasarkan pendapat diatas maka yang dimaksud dengan efisiensi biaya adalah tidak membuang waktu dan tenaga, tepat sesuai dengan rencana dan tujuan. Pada penelitian ini dapat diartikan efisiensi biaya, yaitu biaya yang dikeluarkan atau pengorbanan yang dilakukan tidak melebihi bugdet yang telah ditetapkan manajemen perusahaan. PT. Siix Electronics Indonesia telah menetapkan target pada setiap akhir periode maksimal sebesar USD 1.300.000 untuk semua raw material (baik dari pemasok lokal / local supplier dan oversea material) 


\section{Pengertian Persediaan Bahan Baku}

Persediaan menurut Ristono (2009), persediaan dapat diartikan sebagai barang-barang yang disimpan untuk digunakan atau dijual pada masa atau periode yang akan datang. Persediaan terdiri dari persediaan bahan baku, persediaan barang setengah jadi, dan persediaan barang jadi. Persediaan bahan baku dan barang setengah jadi disimpan sebelum digunakan atau dimasukan ke dalam proses produksi, sedangkan persediaan barang jadi atau barang dagang disimpan sebelum dijual atau dipasarkan.

Menurut Heizer dan Render (2010), persediaan adalah salah satu aset termahal dari banyak perusahaan, mewakili sebanyak 50\% dari keseluruhan modal yang diinvestasikan.

\section{Fungsi Persediaan}

Pada hakikatnya persediaan dapat memperlancar perusahaan dalam proses produksi yang dilakukan secara berkesinambungan setiap harinya, persediaan memiliki fungsi penting bagi perusahaan, antara lain adalah:

1. Agar dapat memenuhi permintaan yang diantisipasi dapat terjadi.

2. Untuk menyeimbangkan produksi dengan distribusi.

3. Untuk memperoleh keuntungan dari potongan kuantitas, karena membeli dalam jumlah yang banyak ada diskon.

4. Untuk hedging dari inflasi dar perubahan harga.

5. Untuk menghindari kekurangan persediaan yang dapat terjadi karena cuaca, kekurangan pasokan, mutu, dan ketidaktepatan pengiriman.

6. Untuk menjaga kelangsungan operasi dengan cara persediaan dalam proses.

\section{Jenis-jenis Persediaan}

Persediaan memiliki beberapa jenis, setiap jenisnya mempunyai karakteristik khusus dan cara pengelolaannya juga berbeda. Menurut Heizer dan Render (2010), untuk mengakomodasi fungsifungsi persediaan, perusahaan harus memlihara empat jenis persediaan, yaitu:

1. Persediaan bahan baku (Raw Material Stock)

Digunakan untuk melakukan decouple (memisahkan) pemasok dari proses produksi. Bagaimanapun juga, pendekatan yang lebih dipilih adalah menghilangkan variabilitas pemasok pada kualitas, kuantitias, atau waktu pengantaran sehingga tidak diperlukan pemisahan.

2. Persediaan barang setangah jadi (work in process-WIP inverntory)

Komponen-komponen atau barang mentah yang telah melewati beberapa proses perubahan, tetapi belum selesai. WIP ada karena waktu yang diperlukan untuk menyelesaikan sebuah produk (waktu siklus).

3. Persediaan pasokan pemeliharaan/perbaikan/operasi

(maintenance, repair, operatingMRO)

Merupakan persediaan-persediaan yang disediakan untuk persediaan pemeliharaan, perbaikan dan prosesproses tetap produktif.

4. Persediaan barang jadi (finish good inventory)

Merupakan produk yang telah selesai dan tinggal menunggu pengiriman. Barang jadi dapat dimasukkan ke persediaan karena permintaan pelanggan di masa mendatang tidak diketahui.

\section{Sistem Pencatatan Persediaan}

Metode pencatatan persediaan ada dua, yaitu metode perpetual dan metode periodik. Metode perpetual disebut juga metode buku, karena setiap jenis persediaan mempunyai kartu persediaan, 
sedangkan metode periodik disebut juga metode fisik. Dikatankan demikian karena pada akhir periode dihitung fisik barang untuk mengetahui persediaan akhir.

Menurut Stice dan Skousen (2009:667), "Ada beberapa macam metode penilain persediaan yang umum digunakan, yaitu: identifikasi khusus, biaya rata-rata (avarege), FIFO dan LIFO.

1. Identifikasi Khusus

Dengan metode ini, biaya dapat dialokasikan ke barang yang terjual selama periode berjalan dan ke barang yang ada di tangan pada akhir periode berdasarkan biaya aktual dari unit tersebut. Metode ini diperlukan untuk mengidentifikasi biaya historis dari unit persediaan. Dengan identifikasi khusus, arus biaya yang dicatat disesuaikan dengan arus fisik barang.

2. Metode Biaya Rata-rata (Average)

Metode ini membebankan biaya rata-rata yang sama ke setiap unit. Metode ini didasarkan pada asumsi bahwa barang yang terjual seharusnya dibebankan dengan biaya rata-rata, yaitu rata-rata tertimbang dari jumlah unit yang dibeli pada tiap harga. Metode rata-rata mengutamakan yang mudah terjangkau untuk dilayani, tidak peduli apakah barang tersebut masuk pertama atau masuk terakhir.

\section{First in First Out (FIFO)}

Metode ini didasarkan pada asumsi bahwa unit yang terjual adalah unit yang terlebih dahulu masuk. FIFO dapat dianggap sebuah pendekatan yang logis dan realistis terhadap arus biaya

4. Last in First Out (LIFO)

Metode ini didasarkan pada asumsi bahwa unit yang paling barulah yang terjual. Jika LIFO digunakan dalam waktu yang lama, maka perbedaan antara nilai persediaan saat ini dengan biaya LIFO menjadi semakin besar.

\section{Biaya Persediaan Bahan Baku}

Biaya bahan baku merupakan komponen biaya yang terbesar dalam pembuatan produk jadi. Dalam perusahaan manufaktur, bahan baku diolah menjadi produk jadi dengan mengeluarkan biaya konversi. Bahan yang digunakan untuk produksi diklasifikasikan menjadi bahan baku (bahan langsung) dan bahan pembantu (bahan tidak langsung). Bahan langsung yaitu bahan yang digunakan untuk produksi yang dapat diidentifikasikan ke produk. Biaya bahan baku dan biaya tenaga kerja langsung merupakan biaya utama (prime cost) yang dibebankan kepada persediaan produk dalam proses. Bahan tidak langsung meliputi semua bahan yang bukan merupakan bahan baku. Biaya bahan tidak langsung dibebankan pada biaya overhead pabrik saat bahan tersebut digunakan untuk produksi. Menurut Heizer dan Render (2010), biaya persediaan dapat dibedakan atas:

1. Biaya penyimpanan (holding cost) Adalah biaya yang terkait dengan menyimpan atau "membawa" persediaan selama waktu tertentu. Oleh karena itu, biaya penyimpanan juga mencakup biaya barang usang dan biaya yang terkait penyimpanan, seperti asuransi, pegawai tambahan, dan pembayaran bunga.

2. Biaya pemesanan (ordering cost) Biaya pemesanan mencakup biaya dari persediaan, formulir, proses pesanan, pembelian, dukungan administrasi, dll. Ketika pesanan sedang diproduksi, baya pemesanan juga ada, tetapi mereka adalah bagian dari biaya penyetelan.

3. Biaya penyetelan (setup cost)

Adalah biaya untuk mempersiapkan sebuah mesin atau proses untuk membaut 
sebuah pesanan. Ini menyertakan waktu dan tenaga kerja

Penerapan biaya pada persediaan raw material PT. SIIX Electronics Indonesia hanya ditekankan pada harga barang tersebut, karena semua harga beli bahan baku berdasarkan quotation yang supplier kirim sudah mencakup semua, termasuk transportasi.

\section{Penelitian Terdahulu}

1. Alex Tarukdatu Naibaho (2013) Analisis Pengendalian Iternal Persediaan Bahan Baku Terhadap Efektifitas Pengelolaan Persediaan Bahan Baku. Hasil penelitian:

1. Pada lingkungan pengendalian, masih ada sebagian karyawan yang belum memenuhi peraturan dan kebijakan yang ditetapkan oleh perusahaan.

2. Adanya perangkapan fungsi yaitu fungsi penerimaan dan penyimpanan dilakukan oleh bagian gudang.

2. Nanik Sunarni, Kertahadi, Devi Farah Azizah (2014) dengan judul Menganilis Pelaksanaan Prosedur Persediaan Bahan Baku Dalam Mendukung Efektivitas Pengendalian Internal. Hasil penelitian:

1. Pelaksanaan prosedur persediaan bahan baku di PG Ngadirejo Kras-Kediri sudah dilaksanakan sesuai dengan prosedur perusahaan, fungsi-fungsi yang terkait dan dokumen yang digunakan sudah baik.

2. Pelaksanaan prosedur persediaan bahan baku dalam mendukung efektifitas pengendalian internal baik.

\section{METODOLOGI PENELITIAN}

1. Tempat dan Waktu Penelitian

a) Tempat penelitian

PT.Siix Electronics Indonesia yang beralamat di Jl. Gaharu Lot 218-219 BIP Muka Kuning, Batam.

b) Waktu Penelitian

November 2017 - Februari 2017

Jenis Penelitian
Jenis penelitian yang digunakan dalam penelitian ini adalah metode penelitian deskriptif kualitatif. Menggunakan metode ilmiah untuk mengungkapkan suatu fenomena dengan cara mendeskripsikan data dan fakta melalui kata-kata secara menyeluruh terhadap subjek penelitian. Tipe penelitian deskriptif yaitu penelitian yang bertujuan untuk mendeskripsikan secara terperinci mengenai fenomena-fenomena social tertentu yang berkenaan dengan masalah yang diteliti.

\section{Sumber Data}

a. Data Primer

b. Data Sekunder

\section{Teknik Pengumpulan Data}

a. Studi Pustaka

b. Wawancara

c. Dokumentasi

d. Observasi

\section{Teknik Analisis Data}

Metode analisis data yang digunakan adalah metode deskriptif yakni meneliti status kelompok manusia, obyek, suatu kondisi, sistem pemikiran, atau pun suatu kelas peristiwa pada masa sekarang. Tujuan dari penelitian deskriptif adalah untuk mmbuat deskripsi, gambaran secara sistematis, faktual dan akurat mengenai fakta-fakta, sifat-sifat serta hubungan antar fenomena yang diteliti. Metode deskriptif kulitatif dilakukan dengan cara sebagai berikut:

1. Analisis data sebelum di lapangan

2. Analisis data di lapangan

a. Data Reduction (Reduksi Data) Mereduksi data berarti merangkum, memilih hal-hal yang pokok.

b. Data Display (Penyajian data)

Dalam penelitian kualitatif, penyajian data bisa dilakukan dalam bentuk uraian singkat, bagan, 
hubungan antar kategori, flowchart, dll.

c. Verification (Penarikan kesimpulan)

Kesimpulan dalam penelitian kualitatif adalah merupakan temuan baru yang sebelumnya belum pernah ada. Temuan dapat berupa deskripsi atau gambaran suatu obyek yang sebelumnya masih remang-remang atau gelap.

\section{HASIL PENELITIAN DAN PEMBAHASAN}

\section{Gambaran Umum Profil Perusahaan}

PT. SIIX Electronics Indonesia didirikan di Batam pada April 1994 dengan memproduksi Printed Circuit Board (PCB). Pada awal berdirinya perusahaan ini bernama PT. Leo Sakata Electronics yang merupakan penggabungan antara SIIX Singapore Pte.Ltd dan Leo Sakata Electronics Pte.Ltd. Pada tahun 1999 SIIX Singapore Pte.Ltd membeli $100 \%$ saham PT. Leo Sakata Electronics dan mengubah nama perusahaan tersebut menjadi PT. SIIX Electronics Indonesia.

Pada Januari 2006, PT. SIIX Electronics Indonesia memperluas bidang usahanya, yang pada awalnya hanya memproduksi PCB menjadi memproduksi PCB dan scanner. Perluasan usaha ini diwujudkan dengan melakukan merger dengan PT. PFU Technology Indonesia yang produksi utamanya adalah scanner dengan merk dagang Fujitsu.

\section{Hasil Penelitian}

\section{Pembelian Bahan Baku Dengan Sistem Just in time}

Pemilihan just in time delivery (JIT) dalam proses pengadaan bahan baku di PT. SIIX Electronics Indonesia didasarkan pada sistem pembelian JIT, yaitu meminimalkan jumlah supplier.
Oleh karena itu PT. SIIX Indonesia hanya memiliki 16 pemasok dari Batam dan 1 oversea supplier yang menyediakan lebih dari 2.000 jenis material.

Kebijakan atau langkah-langkah yang digunakan PT. SIIX Electronics Indonesia dalam melaksanakan metode just in time delivery dalam pengadaan bahan baku, yaitu:

1. Mengirimkan forecast sebagai ramalan pemakaian bahan baku.

2. Mengirimkan delivery schedule materials dengan sistem onemonth basis.

3. Mengirimkan Purchase Order (PO) kepada supplier sebagai sebuah kewajiban pembelian bahan baku

4. Komunikasi yang baik antara purchasing material yang bertindak sebagai window dengan pihak supplier.

Bahan Baku Sebagai Unsur Penting Proses Produksi

Bahan baku yang dimaksud dalam penelitian ini adalah semua direct material atau material yang digunakan langsung dalam proses produksi image scanner. Direct material yang digunakan oleh PT. SIIX Electronics Indonesia di supply dari beberapa local supplier dan oversea supplier.

Pengiriman bahan baku oleh supplier akan mengikuti schedule delivery yang telah dikirim oleh purchasing material, sebagaimana mestinya material akan dikirim oleh supplier minimal satu hari sebelum proses produksi untuk meminimalkan penyimpanan, sesuai dengan metode just in time delivery.

\section{Persediaan Bahan Baku}

Persediaan yang ada di warehouse PT. SIIX Electronics Indonesia semuanya adalah bahan baku, karena untuk finish good akan langsung dilakukan shipping pada keesokan harinya pada kondisi 
normal. Kondisi normal yang dimaksud adalah tidak adanya quality issue yang mengharuskan finish good tidak bisa dikirim.

Persediaan bahan baku PT. SIIX Electronics Indonesia pada dasarnya muncul karena berbagai sebab, diantaranya sebagai berikut:

1. Minimum Order Quantity (MOQ)

Beberapa pemasok akan memberikan minimum order quantity (MOQ) sebagai batas minimal pembelian bahan baku.

2. Standard Pack Quantity (SPQ)

Selain MOQ terdapat juga standard pack quantity (SPQ) yang digunakan sebagai acuan pengiriman bahan baku.

3. Proses produksi yang mundur dari jadwal

Produksi PT. SIIX Electronics Indonesia sebenarnya sudah dijadwalkan pada bulan sebelumnya untuk satu bulan penuh. Akan tetapi terkadang dijumpai masalah yang memaksa produksi diundur, bisa pada bulan yang sama dan pada bulan depan.

4. Safety stock sebagai antisipasi barang yang hilang dan rusak

Persediaan bahan baku yang ada sering kali hilang dan rusak karena proses yang dilakukan, oleh karena itu diperlukan safety stock .

\section{Proses Produksi PT. SIIX Electronics} Indonesia

Proses produksi adalah sebagai berikut:

1. Diawali dengan pembuatan Job Order (JO) berdasarkan jadwal produksi terbaru yang berlaku di bulan berjalan oleh planner. Planner akan memasukkan JO tersebut ke dalam sistem, yaitu ORACLE.

2. Langkah selanjutnya, planner akan membuat picking list yang berisi material apa saja yang dibutuhkan dan jumlah pemakaian berdasarkan bagian-bagian dari image scanner tersebut. Proses kitting material dibagi menjadi 2, yaitu:

a. Delivery material secara bertahap dengan jumlah yang relatif kecil.

b. Drop basis, menggunakan sistem drop untuk beberapa jenis material, delivery material akan selesai dalam sekali kirim.

3. Assembly akan dikerjakan menurut bagian-bagian dari image scanner oleh operator produksi menurut bagianbagian image scanner itu sendiri, misalnya: optik, stacker, chuter.

4. Setelah proses assembly, testing dan pemasangan label telah selesai, image scanner akan didistribusikan ke bagian packing dan shipping, untuk selanjutnya akan dilengkapi dengan aksesoris, seperti buku panduan, kabel, DVD, buku garansi. Proses terakhir adalah proses scan barcode serial number.

5. Sebelum image scanner dimasukkan ke dalam container Outgoing Quality Assurance (OQA) akan melakukan sampling check pada finish good yang telah siap packing.

\section{Pengendalian Internal Terhadap Persediaan Bahan Baku}

Pengendalian internal persediaan bahan baku PPIC Departemen PT. SIIX Electronics Indonesia dapat dijelaskan berdasarkan faktor-faktor yang mendukung:

1. Struktur Organisasi

2. Penetapan Wewenang dan Tanggung Jawab

3. Kinerja Operator dan Staff Warehouse

4. Stocktaking

5. Prosedur Kerja

6. Pengaruh Eksternal

7. Kaizen (Continuous Process Improvement) 
Peran Just in time (JIT) Delivery dan Pengendalian Internal Persediaan Terhadap Efisiensi Biaya Persediaan Bahan Baku.

Persediaan bahan baku di PT. SIIX Elecronics Indonesia sudah memiliki target dari manajemen perusahaan maksimal USD 1.300 .000 pada akhir periode.

Unsur-unsur yang menjadi bagian dalam perhitungan biaya persediaan bahan baku di PT. SIIX Electronics Indonesia adalah harga bahan baku itu sendiri yang telah diberikan oleh supplier dalam bentuk quotation. Sehingga dalam penelitian ini tidak ada perhitungan biaya transportasi, biaya tunggu yang harus diperhitungkan. Karena setiap harga bahan baku yang diberikan sudah mencakup semua aspek tersebut, dan tidak memperhitungkan biaya tunggu karena supplier telah mempersiapkan material berdasarkan forecast yang telah dikirim oleh purchasing material dua kali dalam satu bulan sebagai acuan dalam memproduksi material.

Tingkat efisiensi biaya persediaan diukur dengan membandingkan target manejemen untuk total biaya persediaan setiap bulannya sebesar USD 1,300.000, dan dari data Januari 2016-Desember 2017, tahun 2016 PT. SIIX Electronics Indonesia efisien daripada tahun 2017 dalam meminimalkan biaya persediaan. Biaya persediaan bahan baku berada antara USD 839,000 sampai dengan yang tertinggi USD 1,431.000.

\section{PEMBAHASAN}

Peran Just in time Delivery Menurut Data 2016-2017 Terhadap Biaya Persediaan Bahan Baku

Tujuan dari just in time delivery bagi PT. SIIX Electronics Indonesia adalah untuk meminimalkan biaya penyimpanan barang baku. Dengan istilah menyimpan bahan baku di gudang supplier, tanpa mengganggu proses produksi itu sendiri. Ditinjau dari penerapannya, berdasarkan data yang tahun 2016 sampai 2017 bisa memberikan gambaran nyata tentang peran just in time delivery terhadap biaya persediaan bahan baku PT. SIIX Electronics Indonesia pada akhir periodenya.

Pada tahun 2016 PT. SIIX Electronics Indonesia mampu mengendalikan biaya persediaan dengan cukup efisien, hanya tiga kali tidak mampu mencapai target manajemen yaitu dibulan Januari, Februari dan April. Sedangkan pada bulan-bulan lain cukup baik, biaya persediaan berada diantara USD 830,000 - USD 1,247.000.

Berdasarkan data yang diambil tahun 2017 terlihat bahwa total biaya persediaan PT. SIIX Electronics Indonesia tidak efisien bila dibandingkan dengan tahun 2016, tercatat lima kali tidak dapat mencapai target yang telah ditetapkan oleh manajemen.

Mengalami kenaikan persediaan paling tinggi adalah di bulan Januari 2017, persediaan mencapai USD $2,425.802$ yang disebabkan oleh penurunan jadwal produksi secara tibatiba, yaitu mencapai 3.871 units scanner serta hold finish good 13 units scanner dikarenakan tidak ada shipping ke customer dampak dari quality issue, total biaya persediaan finish good mencapai USD 551,239.35.

\section{Peran Pengendalian Internal Terhadap Biaya Persediaan Bahan Baku}

Pengendalian internal persediaan yang baik akan mempengaruhi ketepatan jumlah persediaan bahan baku, yang erat kaitannya dengan biaya persediaan bahan baku pada setiap akhir periode.

Data menunjukkan bahwa efisiensi biaya persediaan PT. SIIX Electronics Indonesia belum bisa tercapai 
karena masih ditemukan discrepancy stock sampai dengan USD 70,000 pada setiap bulannya pada tahun 2016-2017, yang sangat mempengaruhi total biaya persediaan pada setiap bulannya, karena harus dilaporkan sebagai persediaan akan tetapi fisik persediaan tidak sesuai dengan data yang ada.

Discrepancy stock pasti akan sangat mempengaruhi berbagai aspek, yaitu proses produksi, kinerja warehouse dan akurasi data yang dimiliki. Oleh karena itu peneliti melakukan wawancara dengan beberapa staff PPIC Departemen yang berhubungan dengan persediaan bahan baku, mengenai hal-hal apa saja yang terindikasi menjadi penyebab terjadi discrepancy stock di warehouse PT. SIIX Electronics Indonesia. Wawancara dilakukan kepada Supervisor Store, purchasing material, supervisor Incoming Receiving.

1. Prosedur Kerja

Ada beberapa proses kerja yang dilakukan tidak sesuai dengan prosedur kerja yang telah ada, diantaranya adalah sebagai berikut:

a. Beberapa proses kerja di warehouse dilakukan menyimpang dari work instruction (WI), diantaranya adalah sebagai berikut:

1) Menunda proses expansion material dari receiving area ke locator.

2) Menempatkan material kedalam rak yang salah sehingga menyulitkan operator saat akan melakukan proses.

b. Metode FIFO pada pemakaian material sering kali diabaikan oleh karyawan di warehouse.

c. Prosedur material order oleh bagian produksi kepada warehouse, seharusnya memakai form request slip yang sudah ditanda tangani oleh yang melakukan request, di cek oleh leader dan disetujui oleh supervisor. Akan tetapi pada prakteknya, sering meminta material tanpa form request slip, sehingga material dikirim ke bagian produksi tanpa ada verfikasi.

2. Kinerja Operator dan Staff Warehouse

Motivasi bekerja karyawan sangatlah penting karena akan berpengaruh pada performa karyawan atau operator itu sendiri, akan tetapi banyak karyawan yang kurang memiliki motivasi untuk berkembang. Berikut ada beberapa hal yang berhubungan dengan kinerja karyawan yang berpengaruh pada lemahnya pengendalian internal persediaan:

a. Kurangnya rasa tanggung jawab, karena semua persediaan yang ada di warehouse seharusnya menjadi tanggung jawab semua karyawan warehouse.

b. Operator store sering salah dalam menghitung material, baik itu untuk delivery ke produksi dan pada saat stocktaking material per tiga bulan.

3. Stoctaking

a. Waktu yang terbatas untuk menghitung semua material dengan jumlah material yang perlu dihitung cukup banyak.

4. Pihak Eksternal

Pihak eksternal bagi PPIC Departemen ada 2 yaitu, departemen lain di dalam PT. SIIX Electronics Indonesia dan supplier sebagai pengirim material.

a. Departmen produksi sering melakukan order material diluar job order (JO) tanpa menggunakan request part slip. Sehingga material akan digunakan tanpa ada proses pencatatan.

5. Penetapan wewenang dan tanggung jawab

Leadership atau kepemimpinan yang kurang dari leader lapangan akan sangat 
berpengaruh pada kinerja operator warehouse.

\section{Kaizen}

Seharusnya perbaikan didorong dari posisi puncak sampai ke bawah dan pelaksanaannya difokuskan pada perbaikan proses, tetapi dalam pelaksanaannya hanya level atas saja yang berperan sedangkan level bawah tidak begitu mempersoalkan perbaikan.

\section{KESIMPULAN DAN SARAN Kesimpulan}

1. Pengendalian persediaan yang diterapkan oleh PT. SIIX Electronics Indonesia belum mampu berperan banyak pada efisiensi biaya persediaan secara maksimal. Ditandai dengan masih ditemui data tidak sesuai dengan keadaan yang sebenarnya atau discrepancy stock pada persediaan bahan baku di warehouse.

2. Jadwal pengiriman bahan baku yang telah dibuat oleh purchasing material dengan menggunakan metode just in time (JIT) delivery tidak serta merta mempengaruhi efisiensi biaya persedian bahan baku, karena ada faktor-faktor lain yang turut mempengaruhi efisiensi biaya persediaan. Contohnya: perubahan jadwal produksi.

\section{Saran}

Berdasarkan hasil penelitian yang penulis lakukan pada PT. SIIX Electronics Indonesia, penulis mengemukakan saran yang berhubungan dengan pengendalian internal persediaan dan sistem just in time delivery dalam menunjang efisiensi biaya persediaan bahan baku.

1. Harus ada pengawasan yang ketat dalam pelaksanaan prosedur kerja, dan melaksanakan audit proses kerja yang berhubungan dengan persediaan. Melakukan re-training bagi operator dan training leadership bagi posisi leader, assiten supervisor serta membangun budaya kaizen untuk perubahan yang lebih baik. Karena hal ini adalah dasar untuk menguatkan pengendalian persediaan di warehouse.

2. Pelaksanan metode just in time pada delivery material harus diikuti dengan ketepatan jadwal produksi agar just in time bisa berjalan dengan maksimal dan mendukung efisiensi biaya persediaan bahan baku di PT. SIIX Electronics Indonesia.

\section{DAFTAR PUSTAKA}

Adisasmita, Rahardjo. (2011). Pengelolaan Pendapatan dan Anggaran Daerah. Yogyakarta: Graha Ilmu.

Agus, Ristono. (2009). Manajemen Persediaan, Edisi 1. Yogyakarta: Graham Ilmu.

Deitiana, Tita, Dra. (2011). Manajemen Operasional Strategi dan Analisis, Edisi Asli. Jakarta: Mitra Wacana Media. Hasiholan Andrey Pulungan. (2012). Akuntansi Keuangan Dasar Buku Satu. Jakarta: Mitra Wacana Media.

Heizer, Jay dan Barry Render. (2010). Operation ManagementManajemen Operasi, Edisi 9 Buku 1. Jakarta: Salemba Empat. Martono, Ricky. (2015). Manajemen Logistik Terintegrasi, Cetakan 1. Jakarta: Penerbit PPM.

Mulyadi. (2010). Sistem Akuntansi, Edisi ke-3, Cetakan ke-5. Jakarta: Salemba Empat.

(2014). Akuntansi Biaya, Edisi kelima. Yogyakarta: UPP STIM YKPN.

Naibaho, Alex Tarukdatu. (2013). Analisis Pengendalian Internal Persediaan Bahan Baku Terhadap Efektivitas 
pengelolaan Persediaan Bahan Baku. Jurnal: EMBA Vol.1 No.3.

Putra, Christyandhika dan Farida Idayati. (2014). Penerapan Metode Just in Time Untuk Meningkatkan Efisiensi Biaya Persediaan Bahan Baku. Jurnal: Ilmu \& Riset Akuntansi Vol. 3 No.1.

Sakkung, Carien Valerie dan Candra Sinuriya. (2011). Perbandingan Metode EOQ (Economic Order Quantity) dan JIT (Just in Time) Terhadap Efisiensi Biaya Persediaan dan Kinerja NonKeuangan (Studi Kasus Pada PT. Indoto Tirta Mulia). Jurnal: Ilmiah Akuntansi No.5. Santoso Iman, Se.MM.,Ak. (2007). Akuntansi Keuangan Menengah (Intermediate Accounting). Bandung: PT Refika Editam.

Stice, Earl K, James D Stice dan Fred Skousen. (2009). Akuntansi Keuangan Menengah, Edisi 16 Buku 2. Edisi Bahasa Indonesia. Terjemah Oleh Ali Akbar. Jakarta: PT. Salemba.

Sugiyono. (2012). Metode Penelitian Kuantitatif, Kualitatif dan R\&D. Bandung: Alfabeta. 